\title{
Psikoedukasi Pengaruh Gadget Terhadap Pelajar Didunia Pendidikan Sekolah Menengah Kejuruan
}

\section{Psychoeducation The Effect of Gadgets on Students in the World of Vocational High School Education}

\author{
Dwi Iramadhani(1), Rini Julistia(2(2) \& Zurratul Muna(3) \\ Program Studi Psikologi, Fakultas Kedokteran, Universitas Malikussaleh, Indonesia
}

Disubmit: 03 Desember 2020; Diproses: 03 Desember 2020; Diaccept: 06 Juli 2021; Dipublish: 02 Agustus 2021

*Corresponding uthor: E-mail: rini.julistia@unimal.ac.id

\begin{abstract}
Abstrak
Kecenderungan penggunaan gadget secara tidak bertanggung jawab, berlebihan dan tidak tepat pada akhirnya bisa menjadikan individu atau siswa/i bersikap tidak perduli pada lingkunganya baik pada lingkungan keluarga, masyarakat dan lingkungan pendidikan. Penggunaan gadget secara berkelanjutan dan tidak bertanggung jawab juga akan berdampak buruk bagiindividu dalam kesehariannya. Tujuan dari psikoedukasi ini adalah untuk meningkatkan pengetahuan pada penggunaan gadget terutama dalam pendidikan agar siswa dan siswi dapat menggunakan gadget dengan bertanggung jawab dan tidak ketergantungan. Kegiatan ini terbagi menjadi 3 sub bagian yakni kegiatan pretest, kemudian pada kegiatan kedua yaitu kegiatan psikoedukasi dan kegiatan ketiga yaitu posttest. Hasil yang diperoleh menunjukkan bahwa saat pre test 25 dari 35 siswa/i memiliki kategori tinggi kemudian setelah mengikuti psikoedukasi, lima hari kemudian diukur Post Test diperoleh hasil terdapat 33 siswa/i yang berada pada kategori rendah sedangkan sisanya 2 orang berada pada kategori tinggi. berdasarkan hasil tersebut, dapat diambil kesimpulan bahwa setelah mengikuti kegiatan psikoedukasi pengaruh gadget terhadap pelajar didunia pendidikan, siswa/i dapat meningkatkan kesadarannya akan fungsi gadget sehingga dapat mengunakan gadget dalam hal yang positif.
\end{abstract}

Kata Kunci: Psikoedukasi; Gadget.

\begin{abstract}
The tendency to use gadgets irresponsibly, excessively and inappropriately can make individuals or students not care about their environment, family, community and educational environment. Sustainable and irresponsible use of gadgets will also have a negative impact on individuals in their daily lives. The purpose of this service is to increase knowledge on the use of gadgets, especially in education so the students can use gadgets responsibly and not dependently. This activity is divided into 3 sections: pretest, psychoeducation and posttest. The results obtained showed that during the pre-test 25 of the 35 students were in the high category then after participating in psychoeducation, five days later the Post Test showed that there were 33 students who were in the low category while the remaining 2 peopl have high category. the results indicate thatAfter psychoeducation participated, students can increase their awareness of gadget functions so that they can use gadgets in a positive way.
\end{abstract}

Keywords: Psychoeducation; Gadgets

DOI: https://doi.org/10.51849/j-p3k.v2i2.70

Rekomendasi mensitasi :

Iramadhani D, Julistia R \& Muna Z. (2021), Psikoedukasi Pengaruh Gadget Terhadap Pelajar Didunia Pendidikan Sekolah Menengah Kejuruan. Jurnal Penelitian Pendidikan, Psikologi dan Kesehatan (J-P3K), 2 (2): 96-101. 


\section{PENDAHULUAN}

Sejak 2019, Pandemi covid-19 telah menyebar secara global, virus ini menyebar dengan sangat cepat diberbagai belahan dunia termasuk Indonesia hingga mencapai lebih dari 8,2 juta kasus yang tersebar di 213 negara (Fatia, 2020). Kondisi ini tentu tidak mudah karena harus dilakukan secara tiba-tiba, banyak guru dan peserta didik tidak siap menghadapi situasi pandemi ini (Rahmad, 2018). Dalam situasi tersebut, guru memanfaatkan alat komunikasi sebagai sarana pembelajaran yang dapat menjangkau peserta didik maupun orangtua, alat komunikasi yang banyak dimanfaatkan dalam pembelajaran daring antara lain komputer, notebook, dan gadget (Aswadi \& Lismayanti, 2019).

Gagdet dalam hal ini merupakan salah satu bentuk nyata dari kemajuan Ilmu pengetahuan dan teknologi pada saat ini dan yang akan datang, sekarang ini setiap orang diseluruh dunia pasti sudah memiliki gadget, pengguna gadget saat ini tidak hanya berasal dari kalangan pekerja, tetapi juga semua kalangan seperti siswa/i, guru menggunakan gadget dalam kegiatan mereka tidak hanya untuk keperluan sehari-hari namun juga untuk proses belajar mengajar (Chusna,2017).

Gadget dengan bantuan internet banyak membantu kebutuhan kita seperti memesan makanan, ngobrol dengan teman atau grup, membeli tiket, menggunakan internet banking, update status di media sosial, mencari pekerjaan, bermain game, bahkan tak sedikit yang mengedit video di smartphonenya (Hakam, Levani, \& Utama, 2020). Namun kecenderungan penggunaan gadget secara tidak bertanggung jawab, berlebihan dan tidak tepat pada akhirnya bisa menjadikan individu atau siswa/i bersikap tidak perduli pada lingkunganya baik pada lingkungan keluarga, masyarakat dan lingkungan pendidikan. Seperti menimbulkan kesenjangan soisal diantara individu yang memiliki gadget dengan individu yang tidak memiliki gadget (Santrock, 2011).

Penggunaan gadget secara berkelanjutan dan tidak bertanggung jawab juga akan berdampak buruk bagi pola perilaku individu dalam kesehariannya (Hakam, Levani, \& Utama, 2020). Banyaknya fitur atau aplikasi pada gadget yang sebenarnya tidak sesuai dengan usia individu yang menggunakan, dan diperparah dengan kurangnnya akan nilai norma, etika, edukasi dan agama yang bisa menyebakan individu berprilaku menyimpang (Aswadi, Lismayanti, 2019). Selain itu semakin sering individu menggunakan gadget terutama dalam jarak pandang yang tidak ideal akan menganggu kesehatan terutama pada mata. Selain itu penggunaan gadget tanpa bimbingan akan mengurangi minat baca (Rahmad, 2018).

Sehingga perilaku penggunaan gadget perlu dikontrol dengan baik terlebih pada masa pandemi covid-19 yang melakukan pembelajaran berbasis online atau elearning (Hakam \& Levani, 2020). Jika tidak dikelola dengan bijak, metode pembelajaran tersebut dapat memposisikan siswa/i untuk selalu menggunakan internet di sebagian besar waktu kesehariannya sehingga perlu diidentifikasi, dan ditanggulangi secara serius (Harjanto \& Sumunar, 2018).

Berdasarkan latar belakang diatas, penulis melakukan psikoedukasi pengaruh gadget terhadap pelajar di dunia 
pendidikan pada siswa/i sekolah menengah kejuruan negeri 1 Dewantara, Aceh Utara.

Tujuan dari psikoedukasi adalah untuk meningkatkan pengetahuan pada penggunaan gadget terutama dalam pendidikan agar siswa/i dapat menggunakan gadget dengan bertanggung jawab dan tidak ketergantungan.

\section{METODE PELAKSANAAN}

Tahapan Pelaksanaan Kegiatan ini adalah sebagai berikut:

a. Persiapan Peserta

Peserta kegiatan psikoedukasi Pengaruh Gadget Terhadap Pelajar di Dunia Pendidikan Sekolah Menengah Kejuruan adalah siswa/i kelas XII tahun ajaran 2020/2021 di SMK Negeri 1 Dewantara, Aceh Utara.Jumlah peserta yang ikut dalam kegiatan ini adalah 35 siswa, 3 mahasiswa, dan 3 dosen Psikologi yang mendampingi.

b. PreTest Dan Post Test Kecanduan Gadget

Pada kegiatan Pretest siswa/i dibagi menjadi 2 kelompok kemudian di tempatkan pada dua kelas yang berbeda. Kelas pertama terdiri dari 18 siswa dan kelas kedua terdiri dari 17 siswa. Setelah memberikan psikoedukasi, 5 hari kemudian tepatnya tanggal 30 November 2020 siswa/i melaksanakan posttest. Pada kegiatan postest siswa/i dibagi menjadi 2 kelompok kemudian di tempatkan pada dua kelas yang berbeda. Kelas pertama terdiri dari 18 siswa dan kelas kedua terdiri dari 17 siswa.

c. Psikoedukasi Pengaruh Gadget Terhadap Pelajar di Dunia Pendidikan Sekolah Menengah Kejuruan
Pada kegiatan psikoedukasi, siswa/i dipandu untuk mengetahui pengertian gadget, penggunaannya dalam pendidikan, manfaat dan kerugian dalam menggunakan gadget.

\section{HASIL DAN LUARAN YANG DICAPAI}

Kegiatan ini dihadiri oleh 35 orang Siswa/i. Kegiatan psikoedukasi ini terbagi menjadi tiga sub kegiatan: yang pertama adalah kegiatan pre test, yang kedua psikoedukasi dan yang ketiga post test. Pada kegiatan pertama dilakukan pre test untuk melihat sejauh mana kecanduan siswa/i dalam menggunakan gadget. Aitem dalam pre test berjumlah 30 aitem. Berdasarkan hasil yang di peroleh melalui pretest maka di dapatkan 25 siswa/i yang memiliki kategori tinggi dalam penggunaan gadget (kecanduan gadget) sedangkan sisanya sebanya 15 orang siswa/i dalam kategori rendah dalam penggunaan gadget (tidak mengalami kecanduan gadget).

Tabel 1. Gambaran Hasil Pre Test

\begin{tabular}{cll}
\hline No. & Jumlah & Kategori \\
\hline 1. & 25 & Tinggi \\
2. & 10 & Rendah \\
\hline
\end{tabular}

Pada kegiatan kedua yaitu kegiatan psikoedukasi pengaruh gadget terhadap pelajar di dunia pendidikan sekolah menengah kejuruan dilakukan agar siswa/i mengetahui penggunaan gadget dalam pendidikan sehingga siswa/i tidak melakukan pelanggaran dalam penggunaan gadget terutama yang memiliki koneksi dengan internet serta untuk menghindari terjadinya adiksi gadget. 
Pada kegiatan Ketiga yaitu kegiatan post test untuk melihat sejauh mana psikoedukasi memiliki efek pada siswa/i SMK Negeri 1 Dewantara terhadap penggunaan gadget. Berdasarkan hasil yang diperoleh melalui post test didapatkan bahwa 33 siswa/i memiliki kategori rendah dalam penggunaan gadget (tidak mengalami kecanduan gadget), sedangkan dua siswa/i lagi memiliki kategori yang tinggi dalam penggunaan gadget.

Tabel 2. Gambaran Post Test

\begin{tabular}{lll}
\hline No. & Jumlah & Kategori \\
\hline 1. & 33 & Tinggi \\
2. & 2 & Rendah \\
\hline
\end{tabular}

Dari tabel diatas dapat diambil kesimpulan bahwa hampir semua siswa/i yang mengikuti psikoedukasi telah mengetahui positif dan negative penggunaan gadget, sehingga siswa/i dapat menggunakan gadget sesuai dengan kebutuhan mereka. Gadget merupakan suatu instrument yang memiliki tujuan dan fungsi praktis secara spesifik dirancang lebih canggih dibandingkan dengan teknologi yang diciptakan sebelumnya (Goswani, 2015). Gadget memiliki perbedaan dengan perangkat elektronik lainnya, seiring waktu gadget menyajikan teknologi terbaru yang memiliki banyak fungsi dan membuat hidup penggunanya semakin praktis. Melalui gadget komunikasi menjadi lebih mudah, gadget dapat digunakan sebagai sarana musik, alat dokumentasi, juga sebagai sarana hiburan seperti game dan sosial media (Noegoroho, 2010).

Penggunaan gadget bukan hanya sebagai hiburan semata, banyak manfaat gadget yang dapat diperoleh jika penggunanya memanfaatkan penggunaan gadget secara positif. Seperti penggunaan gadget dalam dunia pendidikan sekolah menengah kejuruan. Kondisi covid-19 yang memaksa peserta didik harus "belajar dirumah", menuntut siswa/i untuk melibatkan gadget dalam proses belajar. Proses belajar mengajar menjadi tetap terlaksana meskipun pelaksaannya dilakukan secara daring, diawal proses belajar daring siswa/i kesulitan dalam membiasakan diri menggunakan perangkat gadget. Namun beriring waktu siswa/i dapat menggunakan gadget sebagai media belajar seperti diantaranya mengakses informasi mengenai mata pelajaran, menyimpan berbagai data terkait dengan tugas sekolah, menggunakan sosial media seperti instagram untuk mempromosikan kemampuan diri seperti flyer terkait tugas sekolah, serta mengunakan aplikasi zoom dan google meet untuk mengikuti proses belajar mengajar.

Pemanfaatan media pembelajaran dengan menggunakan gadget juga memudahkan siswa/i dalam memperoleh informasi menjadi lebih cepat dan menyenangan. Sebagaimana hasil penelitian Susanti (2018) yang menunjukkan bahwa penggunaan media pembelajaran dapat membangkitkan minat siswa/i mengikuti proses pembelajaran. Selain itu media gadget juga dapat memberikan rangsangan dalam kegiatan belajar siswa sehingga hasil belajar siswa menjadi lebih baik. Hasil tersebut diatas sejalan dengan pendapat Dominick (dalam Maulana dan Gumelar, 2012) yang menjelaskan bahwa ada beberapa alasan siswa/i menggunakan gadget sebagai alat untuk kelangsungan hidupnya yaitu 
cognition atau pemikiran, pemikiran ini diperoleh dari adanya niat dan perilaku siswa dalam mencari informasi beragam melalui gadget; diversion yaitu gadget dijadikan sarana untuk memenuhi kebutuhan emosionalnya melalui beragam fitur dan aplikasi untuk bersantai dan memenuhi kebutuhan emosionalnya; dan social utility yaitu memenuhi alasan siswa dalam menggunakan gadget sebagai alat untuk berkomunikasi dengan orang-orang terdekatnya seperti teman dan orang tua.

Selain sebagai media belajar, gadget juga memiliki dampak negatif seperti akses informasi negative yang menjadi lebih mudah diakses. Seperti konten pornografi, kekerasan dalam game atau film serta penggunaan gadget yang berlebihan sehingga menyebabkan penggunanya menjadi kecanduan. Kondisi tersebut membuat pengguna gadget dalam dunia pendidikan sekolah menengah kejuruan sebagai media proses belajar mengajar harus lebih berhati-hati dalam menggunakannya agar penggunaannya tepat sasaran serta tidak berlebihan.

Hal ini sesuai dengan pendapat Saroinsong (2016) yang menyatakan bahwa penggunaan gadget yang berlebihan akan berdampak merugikan pada keterampilan interpersonal siswa/i seperti akses informasi yang negatif serta prestasi belajar yang menurun karena menggunakan gadget untuk bermain daripada harus belajar.

\section{SIMPULAN}

Kegiatan psikoedukasi ini dilakukan dalam bentuk psikoedukasi dengan judul "Pengaruh Gadget Terhadap Pelajar di Dunia Pendidikan". Psikoedukasi dilaksanakan pada Siswa/i SMK Negeri 1
Dewantara, Aceh Utara. Kegiatan psikoedukasi ini terbagi menjadi 3 sub bagian yakni kegiatan pretest, kegiatan pretest dilakukan untuk melihat sejauh mana Siswa/I SMK Negeri 1 kecanduan mengunakan Gadget. Kemudian pada kegiatan kedua yaitu kegiatan psikoedukasi pengaruh Gadget guna memberikan gambaran mengenai penggunaan gadget, kerugian penggunaan gadget serta manfaat gadget dalam dunia pendidikan.

Kemudian kegiatan ketiga yaitu posttest, post test diberikan lima hari setelah psikoedukasi dilakukan. Dalam hal ini, hasil yang diperoleh menunjukkan bahwa saat pre test 25 dari 35 siswa/i memiliki kategori tinggi kemudian setelah mengikuti psikoedukasi "Pengaruh Gadget Terhadap Pelajar di Dunia Pendidikan", lima hari kemudian diukur Post Test diperoleh hasil terdapat 33 siswa/i yang berada pada kategori rendah sedangkan sisanya 2 orang. Berdasarkan hasil tersebut juga dapat diambil kesimpulan bahwa setelah mengikuti kegiatan ini Siswa/i dapat meningkatkan kesadarannya akan fungsi gadget sehingga dapat mengunakan gadget dalam hal yang positif.

\section{UCAPAN TERIMAKASIH}

Terimakasih LPPM Universitas Malikussaleh yang telah mengadakan program pendanaan PNPB bagi para dosen di ilingkungan kampus.

Terimakasih kepada Fakultas Kedokteran dan Program Studi Psikologi yang memberikan kesempatan dan dukungan kepada psikoedukasi sehingga psikoedukasi ini terlaksana dengan baik.

Terimakasih kepada siswa yang bersedia menjadi subjek, mahasiswa yang terlibat sebagai team psikoedukasi dan 
pihak-pihak yang terlibat maupun mendukung penelitian ini hingga terlaksana dengan baik.

\section{DAFTAR PUSTAKA}

Aswadi, D. \& Lismayanti, H. 2019. Dampak Penggunaan Smartphone terhadap Pendidikan Karakter Anak di Era Milenial. Jurnal Bahasa, Sastra dan Pengajarannya , 4 (1).

Chusna, P. A. 2017. Pengaruh Media Gadget pada Perkembangan Karakter Anak. Dinamika Penelitian: Media Komunikasi Sosial Keagamaan , 17 (2): 315-330.

Fatia, S, N, 2020. Update Virus Corona diDunia: Indonesia Berada di Peringkat 31 Dunia. Diunduh di https://www.pikiranrakyat.com/internasional/pr01566252/update-virus-corona-di-duniarabu-17-juni-2020-indonesia-berada-diperingkat-31-dunia/tanggal tanggal 17 Juni 2020

Goswami, dkk. 2015. Impact of Mobile Phone Addiction on Adolesent's life: A Literature Review. Internasional Journal of Home Science. 2(1), 69-74

Hakam, M. T., Levani, Y, \& Utama, M. R. 2020. Potensi Adiksi Penggunaan Internet pada Remaja Indonesia di Periode Awal Pandemi. Hang Tuah Medical Journal , 17 (2); 102-115.

Harjanto, T., Sumunar, D. S. E. W. 2018. Tantangan Dan Peluang Pembelajaran Dalam Jaringan: Studi Kasus Implementas Elok (E-Learning: Open For Knowledge Sharing) Pada Mahasiswa Profesi Ners. Jurnal Keperawatan Respati Yogyakarta, 5; 24-28.

Jung, Carl G. 2015. Mobile Phone Addiction and Loneliness among Teenagers. The Internasional Journal of Indian Psychology. 2(4), 1

Maulana \& Gumelar. 2012. Komunikasi Psikologi. Yogyakarta: Graha Ilmu

Noegoroho, A. 2010. Teknologi Komunikasi. Yogyakarta : Graha Ilmu.

Rahmad, S, T. 2018. Pola Asuh Efektif Untuk Mendidik Anak Di Era Digital. Jakarta: Rineka Cipta.

Santrock, J, W. 2011. Psikologi Perkembangan 7ed. Terjemahan: S. Genis. Jakarta : Erlangga.

Susanti, A. D. 2018. Pengaruh Pemanfaatan Gadget Dalam Aktifitas Belajar Untuk Meningkatkan Hasil Belajar PPKN Siswa
diKelas XI IIS SMA Negeri 1 Seputih Mataram, Skripsi. Fakultas keguruan dan ilmu pendidikan Universitas Lampung,.

Saroinsong, W. P. 2016. Gadget Usage Inhibited Interpersonal Intelligence Of Children On Ages 6-8 Years Old. Journal of Scientific, Technology, Educational. 775-781.

Tara, L., Nurmalisa, \& Yunisca. 2014. Pengaruh Penggunaan Gadget Pada Peserta Didik Terhadap Interaksi Sosial. Jurnal kultur demokrasi. 2(2), 5-7. 